\title{
Философия
}

DOI: $10.17805 / g g z .2017 .5 .8$

\section{О теоретико-методологических основаниях биосоциологии}

\author{
Б. Г. Юдин \\ ИнСТИТУТ ФИЛОСОФИИ РАН
}

Статья составлена из ответов выдающегося российского философа и всемирно признанного специалиста по биоэтике Бориса Григорьевича Юдина (1943-2017) на вопросы Вал. А. Лукова в связи с формированием нового научного направления «биосоциология молодежи». Ответы содержатся в частном письме, которое Б. Г. Юдин направил 29.07.2013 г. В полном объеме публикуются впервые.

Ключевые слова: биосоциология; трансгуманизм; молодежь; дети-индиго

\section{On Theoretical and Methodological Foundations of Biosociology}

\author{
B. G. YUDIN \\ INSTITUTE OF PHILOSOPHY, RAS
}

The article comprises responses of an outstanding Russian philosopher and internationally recognized specialist in bioethics Boris Yudin (1945-2017) to the questions of Valery Lukov in connection with the formation of a new research area "the biosociology of youth". The answers were sent by B. G. Yudin in a private letter of July 29, 2013. This is the first full publication. Keywords: biosociology; transhumanism; youth; indigo children

\section{ВВЕАЕНИЕ}

Борис Григорьевич Юдин (1943-2017) был одним из тех немногих исследователей, кто осмысливал комплексные проблемы человека именно как комплексные, т. е. междисциплинарные по своей природе. Это отразилось и на его трудах в Институте человека РАН, директором которого он был многие годы, а именно на толковании этики науки (Фролов, Юдин, 1986, 2009), человеческого потенциала (Человеческий потенциал ..., 2002ab, 2007), гуманитарной экспертизы (Юдин, 2005), оценки последствий биомедицинских исследований (Философия биомедицинских исследований ..., 2004) и других междисциплинарных проблем. Широта подхода отличала его проекты в Институте философии, где он руководил отделом комплексных проблем исследования человека, и в Институте фундаментальных и прикладных исследований МосГУ, где сформировался под его руководством Центр биоэтики. Некоторые из прежних, но тем не менее актуальных проблем человека он продолжил изучать с учетом новых условий, которые перед ним открылись в МосГУ (Основы гуманитарной экспертизы ..., 2008аb; Юдин, Ауков, 2006; Юдин, 2008, 2011, 2013). 
Как член редакционного совета научного журнала «Знание. Понимание. Умение» он еще в 2011 г. познакомился со статьей «Биосоциология», которая в самом приближенном виде свидетельствовала о формировании нового научного направления, связанного с многомерностью человека. В статье, в частности, отмечалось: «Биосоциология - формирующаяся научная концепция междисциплинарного характера и практика исследования сложных по природе явлений современной общественной жизни, исходящие из неразрывной связи биологического и социального компонентов в жизни человека и человеческих сообществ (социальных общностей). Важная задача биосоциологии - выявить возможные трансформации общества через накопление в новых поколениях критической массы биологических и интеллектуальных (под воздействием факторов внешней среды обитания и вызванных искусственными средствами), а также социокультурных изменений. По своей прогностической направленности биосоциология может рассматриваться в одном ряду с биоэтикой, ее развитие тесно связано с институционализацией гуманитарной экспертизы как способа сознательной регуляции изменений в человеке и обществе в условиях, когда технологически становится возможным в массовых масштабах осуществлять инновации, касающиеся самой природы человеческого и социального» (Ауков, 2011: 319). На этой основе готовилась монография (Иуков, 2013), для которой видные ученые России, разумеется, и Б. Г. Юдин, и начинающие исследователи человека высказывали свои мнения относительно некоторых дискуссионных проблем, которые были представлены в следующих вопросах: «Уважаемый Борис Григорьевич! Обращаюсь к Вам как к признанному эксперту в области комплексных проблем изучения человека, академику Международной академии наук (IAS) в связи с проводимым на базе Института фундаментальных и прикладных исследований Московского гуманитарного университета при поддержке Русского отделения Международной академии наук (IAS) и РФФИ междисциплинарным исследованием «Биосоциология молодежи: теоретико-методологические основания». В рамках исследования осуществляется социально-гуманитарная экспертиза, которая направлена на выявление проблемных полей исследования современной молодежи в контексте кардинальных структурных перемен в обществе, относящихся ко всем сферам человеческой жизни, включая и эксперименты, затрагивающие биологическую природу человека. Прошу высказать свое мнение по вопросам, которые поставлены ниже. Как и в других экспертных опросах, большое значение имеет обоснование Вашей позиции». Аалее были представлены сами вопросы, которые составили пять следующих групп:

1. Считаете ли Вы, что в последние десятилетия среди молодежи происходят изменения, которые затрагивают в значительном числе случаев ее телесность, интеллектуальный и социокультурный потенциал? Насколько правдоподобны утверждения о массовом появлении «детей-индиго» и Аругие гипотезы о новом поколении, которое заметно отличается по биопсихическим и социокультурным свойствам от старших поколений?

2. Встречались ди Вам в Вашей практике молодые люди с особыми биосоциальными свойствами, умственными, творческими и другими способностями, которые Аали Вам повод размышлять, что это не уникальные случаи, а свидетельство возникающих новых тенденций в развитии человека и общества? Что это за случаи и что это за тенденции?

3. В научных сообществах обсужАается вопрос о возможностях решительного изменения продолжительности жизни человека при помощи новых биомедицинских технологий (включая разработку медицинских нанороботов и т. п.). Получили рас- 
пространение идеи трансгуманизма о скором появлении постчеловека и т. п. Если такие изменения произойдут и человек будет жить 100 и больше лет, сохранятся ли общественные функции молодежи? Какие изменения в ее социализации и ее жизненном становлении можно ожидать? Вообще - будет ли выделяться молодежь как особая социальная группа в таком обществе?

4. Уже имеют место практики проектирования заданных телесных и интеллектуальных свойств ребенка. Насколько реально их массовое применение в ближайшие 25 лет? Какие послеАствия Аля общества они могут иметь? Как их поставить под контроль общества и нужен ли этот контроль?

5. Какие вопросы, связанные с исследованием молодежи, актуальны в сфере Вашей профессиональной Аеятельности? Что Вы считаете Аля себя понятным, а что непонятным в современной молодежи?

В связи с подготовкой монографии по биосоциологии молодежи Б. Г. Юдин прислал в 0:19 ч, т. е. фактически ночью, 29 июля 2013 г. следующее письмо: «Аорогой Валерий Андреевич! Я, возможно, буду первым, кто сегодня поздравит Вас с днем рождения. Желаю Вам всякого блага, а прежде всего - доброго здоровья и надеюсь, что наше продуктивное и содержательное сотрудничество будет продолжаться. В качестве одного из шагов в этом направлении посылаю Вам свои ответы на вопросник по молодежи. Надеюсь, что завтра (точнее, уже сегодня во второй половине дня) будет возможность повидаться. Также (сугубо в предварительном, прикидочном варианте) прошу Вас передать мои поздравления и наитеплейшие пожелания Владимиру Андреевичу. Ваш Б. Г. Юдин».

\section{ОТВЕТЫ Б. Г. ЮАИНА}

К письму были приложены следующие ответы:

1. Считаете ли Вы, что в последние десятилетия среди молодежи происходят изменения, которые затрагивают в значительном числе случаев ее телесность, интеллектуальный и социокультурный потенциал? Насколько правдоподобны утверждения о массовом появлении «детей-индиго» и другие гипотезы о новом поколении, которое заметно отличается по биопсихическим и социокультурным свойствам от старших поколений?

- На мой взгляд, изменения последних десятилетий среди молодежи имеют своей причиной прежде всего раннее приобщение детей к информационно-коммуникационным технологиям; сами же эти технологии чрезвычайно быстро прогрессируют, беспрерывно расширяя спектр возможностей, открываемых ими для пользователей. Аети же, в силу присущей им пластичности восприятия и поведения, того, что их действия и реакции в минимальной степени подчинены стереотипам, скорее осваивают эти возможности. В результате современная культура во многих отношениях оказывается префигуративной в смысле М. Мид, что взрослыми нередко воспринимается как наличие у новых поколений радикальных (и при этом трудно контролируемых!) отличий биопсихического и социокультурного характера. Естественно, такое резкое расширение возможностей выражается и в том, что возрастает диапазон вариаций, в том числе и таких, которые представляются отклонениями от нормы. Вполне возможно, что именно такого рода отклонения порождают представления о массовом появлении «детей-индиго».

Вместе с тем существенно меняется окружающая среда (не только физико-химико-биологическая, но и информационная), в которую попадает рождающийся сего- 
дня ребенок, что не может не воздействовать на его здоровье и развитие. Правда, оценить темпы и глубину такого рода воздействий, а также способности адаптироваться к ним сегодня едва ли возможно. Но, во всяком случае, есть основания связывать констатируемое в последние десятилетия ухудшение здоровья детей с неблагоприятными экологическими изменениями.

2. Встречались ли Вам в Вашей практике молодые люди с особыми биосоциальными свойствами, умственными, творческими и другими способностями, которые дали Вам повод размышлять, что это не уникальные случаи, а свидетельство возникающих новых тенденций в развитии человека и общества? Что это за случаи и что это за тенденции?

- В последние лет двадцать я, к сожалению, имею весьма ограниченный личный опыт общения с молодыми людьми студенческого и менее юного возраста. И хотя за эти годы мне приходилось встречать детей с особыми биосоциальными свойствами и умственными способностями, моих наблюдений явно недостаточно для того, чтобы делать широкие обобщения.

3. В научных сообществах обсуждается вопрос о возможностях решительного изменения продолжительности жизни человека при помощи новых биомедицинских технологий (включая разработку медицинских нанороботов и т. п.). Получили распространение идеи трансгуманизма о скором появлении постчеловека и т. п. Если такие изменения произойдут и человек будет жить 100 и больше лет, сохранятся ли общественные функции молодежи? Какие изменения в ее социализации и ее жизненном становлении можно ожидать? Вообще - будет ли выделяться молодежь как особая социальная группа в таком обществе?

- Сегодня рассматриваются самые разные сценарии тех социальных изменений, которые повлечет за собой резкое увеличение средней продолжительности жизни. Среди них есть и такие, которые связаны с более или менее жестким социальным регулированием, квотированием деторождения. (Нечто подобное уже делается в современном Китае.)

Следует отметить, что лимитирующим фактором - в случае, если сохранится на примерно таком же уровне, как и сейчас, зависимость человечества от потребления естественных ресурсов - при такого рода сценариях может стать уровень развития производительных сил общества и, в частности, то, какова будет та доля населения, которая необходима для содержания как возрастающего количества людей пожилого возраста, так и молодежи. Квота на деторождение при этом будет находиться в зависимости от того, насколько продолжительным станет средний период жизни пожилого человека, в течение которого он будет оставаться лишь потребителем, неспособным ни к какому виду производительной деятельности. Еще одним обстоятельством, которое необходимо принимать во внимание, будет увеличение продолжительности времени (а также увеличение необходимого объема знаний и т. п.), необходимого для подготовки молодого человека к самостоятельной жизни.

Очевидно, квотирование деторождения, когда возможность произвести на свет ребенка станет привилегией, будет сильным стимулом для создания и применения технологий неоевгенического плана, таких, как пренатальная и преимплантационная диагностика. Наряду с этим более жесткому регулированию, не только семейному, но 
и социальному, будет подвергаться здоровье и поведение детей и юношей. Получается, таким образом, что расширение спектра возможностей индивида вследствие технологического прогресса будет каким-то противоречивым образом сочетаться с разнообразными мерами жесткого регулирования.

4. Уже имеют место практики проектирования заданных телесных и интеллектуальных свойств ребенка. Насколько реально их массовое применение в ближайшие 25 лет? Какие последствия для общества они могут иметь? Как их поставить под контроль общества и нужен ли этот контроль?

- Я не думаю, что массовое применение такого рода практик станет реальным в ближайшие четверть века. На мой взгляд, процессы широкого распространения такого рода практик будут носить плавный характер лишь до достижения каких-то пороговых параметров, после которых их рост может принять взрывоподобный, а значит, мало контролируемый характер. Тогда их общественный контроль станет просто-напросто необходимым условием выживания общества. Вместе с тем уже сегодня начаты и получают все большее распространение поиск и апробация различных схем и механизмов общественного регулирования технологий. В частности, все б?льшую роль при этом играет принцип предосторожности, применение которого выходит далеко за рамки той области, где он впервые был сформулирован, т. е. проблематики защиты окружающей среды.

5. Какие вопросы, связанные с исследованием молодежи, актуальны в сфере Вашей профессиональной деятельности? Что Вы считаете для себя понятным, а что непонятным в современной молодежи?

- Исследования молодежи как таковые, вообще говоря, не входят непосредственно в сферу моих профессиональных интересов. Однако в ответах на предыдущие вопросы я так или иначе обозначил целый ряд таких узловых точек, в которых эта проблематика оказывается близко к фокусу моих интересов. На мой взгляд, проблематика молодежи сегодня оказывается тесно связанной с проблематикой технологического прогресса и его влияния на человека и общество. Но связь эта носит крайне сложный и мало понятный характер.

\section{ЗАКАЮЧЕНИЕ}

Ответы Б. Г. Юдина, безусловно, представляют интерес в связи с развитием новых направлений гуманитарного знания. Если в работах начала 2000-х годов он больше был склонен к проблематике поддержания здоровья человека (Здоровье ..., 2003; Социальная справедливость в здравоохранении ..., 2006), то в ответах 2013 г. заметна информационная составляющая, с которой он связывает и перспективы человека, и риски для человеческого рода.

Характерно размышление Б. Г. Юдина о плавном процессе реализации идеи проектирования свойств человека до определенного временного порога, после чего процесс пойдет взрывоподобно и будет малоконтролируемым. Это размышление определяется не только на теоретическом уровне, оно отражает и наблюдения ведущего биоэтика России за изменением ситуации в мировом сообществе.

Ответы Б. Г. Юдина следует иметь в виду при формировании теоретико-методологических основаних биосоциологии, особенно той ее части, которая охватывает перспективы человека. 


\section{СПИСОК АИТЕРАТУРЫ}

3доровье человека: социогуманитарные и медико-биологические аспекты / под ред. Б. Г. Юдина. М. : Ин-т человека РАН, 2003. 288 с.

$\Lambda$ уков, В. А. Биосоциология (2011) // Знание. Понимание. Умение. № 3. С. 319-323.

$\Lambda$ уков, В. А. (2013) Биосоциология молодежи: теоретико-методологические основания : науч. монография. М. : ИзА-во Моск. гуманит. ун-та. 430 с.

Основы гуманитарной экспертизы: методологические и праксеологические аспекты. Вып. 1 (2008а) / под общ. ред. Б. Г. Юдина. М. : ИзА-во Моск. гуманит. ун-та, 2008. 80 с.

Основы гуманитарной экспертизы: методологические и праксеологические аспекты. Вып. 2 (2008b) / под общ. реА. Б. Г. Юдина. М. : ИзА-во Моск. гуманит. ун-та, 2008. 64 с.

Социальная справедливость в здравоохранении: биоэтика и права человека (2006): материады и документы междунар. конференции. Москва, 7-8 декабря 2005 г. : Social Justice in Healthcare: Bioethics and Human Rights / редкол.: Вал. А. Ауков, А. В. Мартыненко, М. В. Рукавишников и др. ; под общ. ред. Б. Г. Юдина. М. : ИзА-во Моск. гуманит. ун-та. 228 с.

Философия биомедицинских исследований: этос науки начала третьего тысячелетия (2004) / отв. ред. Б. Г. Юдин. М. : Ин-т человека РАН. 128 с.

Фролов, И. Т., Юдин, Б. Г. (1986) Этика науки: Проблемы и дискуссии. М. : Политиздат. 399 с.

Фролов, И. Т., Юдин, Б. Г. (2009) Этика науки: Проблемы и дискуссии. 2-е изд., перераб. и доп. М. : Кн. дом « ИИБРОКОМ». $256 \mathrm{c}$.

Человеческий потенциал Парфеньевского района Костромской области (2002а) / отв. ред. С. М. Малков. М. : Ин-т человека РАН. 285 с.

Человеческий потенциал России: интеллектуальное, социальное, культурное измерения (2002b) / под ред. Б. Г. Юдина. М. : Ин-т человека. РАН. 265 с.

Человеческий потенциал как критический ресурс России (2007) / отв. ред. Б. Г. Юдин. М. : ИФ РАН, 2007. $175 \mathrm{c.}$

Юдин Б. Г. (2005) От этической экспертизы к экспертизе гуманитарной // Знание. Понимание. Умение. № 2. С. 126-135.

Юдин, Б. Г. (2008) Медицина и конструирование человека // Знание. Понимание. Умение. № 1. C. 12-20.

Юдин, Б. Г. (2011) Человек как объект технологических воздействий // Человек. №3. C. $5-20$.

Юдин, Б. Г. (2013) Трансгуманизм - наше будущее? // Человек. № 4. С. 5-17.

Юдин, Б. Г., Ауков, В. А. (2006) Гуманитарная экспертиза: К обоснованию исследовательского проекта. М. : ИзА-во Моск. гуманит. ун-та. 38 с.

Аата поступления: 18.11.2017 2.

Юдин Борис Григорьевич (1943-2017) - член-корреспондент РАН, доктор философских наук, профессор, главный научный сотрудник отдела гуманитарной экспертизы и биоэтики Института философии PAH (2015-2017), академик Международной академии наук (IAS, Инсбрук).

Yudin Boris Grigorievich (1943-2017), corresponding member of RAS, Doctor of Philosophy, Professor, chief researcher of the Department of humanitarian expertise and bioethics, Institute of philosophy, Russian Academy of Sciences (2015-2017), full member of the International Academy of Sciences (IAS, Innsbruck).

\section{Аля иитирования:}

Юдин Б. Г. О теоретико-методологических основаниях биосоциологии [Электронный ресурс] // Горизонты гуманитарного знания. 2017. №5. URL: http://journals.mosgu.ru/ggz/article/view/605 (дата обращения: дА.мм.гггг). DOI: 10.17805/ggz.2017.5.8 